\title{
Availability and effectiveness of physiotherapeutic rehabilitation according to subjective assessment of women after mastectomy
}

\author{
Katarzyna $\operatorname{Knott}_{(\mathrm{A}, \mathrm{B}, \mathrm{C}, \mathrm{D}, \mathrm{E}, \mathrm{F}, \mathrm{G})}^{1}$, Małgorzata Starczyńska $_{(\mathrm{A}, \mathrm{E}, \mathrm{F})}$ \\ ${ }^{1}$ Vincent Pol University in Lublin, Poland \\ ${ }^{2}$ Faculty of Health Sciences, Jan Kochanowski University in Kielce, Poland
}

\begin{abstract}
Breast cancer is currently the most dangerous and common malignant neoplasm occurring in women. Diagnosis and treatment of cancers affect women's mental, physical and social functioning. Demands for rehabilitation therapy of women after mastectomy are increasingly high. The aim of the present study was to assess the availability of physiotherapeutic rehabilitation and its effects on the health of women who underwent mastectomy. The study group encompassed 48 women after mastectomy. Diagnostic survey was carried out using the authors ' questionnaire consisting of 20 closed questions. In the study group, $43.75 \%$ of women started rehabilitation one month after the procedure, $35.42 \%$ - two weeks after, $12.50 \%$ - over two months after and $8.33 \%$ - one week after mastectomy. The most satisfied with the availability of rehabilitation were women living in towns with $>100,000$ thousand and with 10,000-100,000 inhabitants. Women from villages and towns with about 10,000 inhabitants were rather dissatisfied. The largest group (29.81\%) consisted of women in whom the physiotherapeutic procedures resulted in improved range of movement of the shoulder girdle on the affected side; swellings decreased in $24.04 \%$ and pain was reduced in $20.19 \%$ of women. Rehabilitation is an integral part of cancer treatment and recovery. In the study group, $46 \%$ of respondents found post-mastectomy rehabilitation effective. The place of residence had moderate effects on satisfaction with availability of health care services. According to patients, physical therapy exercises are most effective while whirlpool massages are least effective.
\end{abstract}

Key words: rehabilitation, mastectomy, physiotherapeutic rehabilitation, breast cancer

\section{Introduction}

Breast cancer is the most common neoplasm in women in Poland and most of the countries worldwide. Despite numerous studies and analyses, in the majority of cases the aetiology of breast cancer cannot be established. Cancer can be induced by several or even a dozen of carcinogenic factors, which additionally hinders the determination of aetiology. Genetic factors are increasingly implied as the cause of breast cancer. In Poland, about $10 \%$ of women with breast cancer have the mutations of BRCA1 and BRCA2 genes, and most likely of BRCA3, p53, and hMLH1 as well. BRCA1 is the most common gene occurring in $50 \%$ of cases $[1,2,3]$. In Poland, 130,000 of new cases were diagnosed in 2000, 85,000 of which resulted in death. Since 2010, the incidence of breast cancer is anticipated to increase to about 160,000 cases and the mortality to about 100,000 [4]. The incidence of breast cancer in the individual geographical regions is associated with the economic and social situation, skin colour, marital status and place of residence. Increased incidence rates are observed in economically endangered regions and in towns [5]. In Poland, above 10,000 new cases are recorded annually; half of them are fatal. Mortality regards not only women newly diagnosed with breast cancer but also those diagnosed earlier or those with breast cancer developing many years before the diagnosis [6]. Anticancer prophylaxis is essential as it can reduce the number of deaths and improve treatment outcomes without high expenditure [7].

\section{Aim}

The aim was subjective assessment of women after mastectomy of availability and effectiveness of physiotherapeutic rehabilitation.

\section{Material and methods}

The study was carried out in the Świętokrzyski Centre of Oncology in January 2014 and encompassed 48 women after mastectomy. Each woman was informed about the aim and anonymity of the study. Diagnostic survey was performed using the authors ' questionnaire consisting of 20 closed questions. Results were statistically analysed and presented in tables.

Table. 1. Age of women

\begin{tabular}{|l|c|c|}
\hline \multicolumn{1}{|c|}{ Age range } & $\mathbf{n}$ & $\mathbf{\%}$ \\
\hline$<25$ years & 0 & 0.00 \\
\hline $26-35$ years & 8 & 16.67 \\
\hline $36-45$ years & 20 & 41.67 \\
\hline$>46$ years & 20 & 41.67 \\
\hline total & $\mathbf{4 8}$ & $\mathbf{1 0 0 . 0 0}$ \\
\hline
\end{tabular}

The largest study group consisted of women aged $36-45$ and $>46$ years $(41.67 \%)$ while the smallest group of those aged $26-35$ years (16.67\%). 
Table 2. Place of residence of women

\begin{tabular}{|l|c|c|}
\hline \multicolumn{1}{|c|}{ Place of residence } & $\mathbf{n}$ & $\mathbf{\%}$ \\
\hline country & 12 & 25.00 \\
\hline town $<10$ thousand inhabitants & 7 & 14.58 \\
\hline $\begin{array}{l}\text { town }-10-100 \text { thousand } \\
\text { inhabitants }\end{array}$ & 9 & 18.75 \\
\hline town $>100$ thousand inhabitants & 20 & 41.67 \\
\hline total & $\mathbf{4 8}$ & $\mathbf{1 0 0 . 0 0}$ \\
\hline
\end{tabular}

The largest study group consisted of women living in towns > 100 thousand inhabitants $(41.67 \%)$ whereas the smallest one of those from towns $<10$ thousand inhabitants $(14.58 \%) ; 25 \%$ of respondents were from villages.

Table 3. Type of mastectomy

\begin{tabular}{|l|c|c|}
\hline \multicolumn{1}{|c|}{ Type of mastectomy } & $\mathbf{n}$ & $\mathbf{\%}$ \\
\hline $\begin{array}{l}\text { Radical (amputation of breast, } \\
\text { axillary lymph nodes, greater } \\
\text { thoracic muscle) }\end{array}$ & 29 & 60.42 \\
\hline $\begin{array}{l}\text { Modified radical (with removal of } \\
\text { lymph nodes) }\end{array}$ & 13 & 27.08 \\
\hline $\begin{array}{l}\text { Simple (without removal of lymph } \\
\text { nodes) }\end{array}$ & 6 & 12.50 \\
\hline total & $\mathbf{4 8}$ & $\mathbf{1 0 0 . 0 0}$ \\
\hline
\end{tabular}

Radical mastectomy was performed in $60.42 \%$ of women, modified radical in $27 \%$ and simple in $13 \%$ of women.

\section{Results}

Table 4. Waiting time for rehabilitation

\begin{tabular}{|l|c|c|}
\hline $\begin{array}{c}\text { Waiting time for } \\
\text { rehabilitation }\end{array}$ & n & \% \\
\hline$\leq$ one week & 4 & 8.33 \\
\hline$\leq$ two weeks & 17 & 35.42 \\
\hline$\leq$ one month & 21 & 43.75 \\
\hline$>$ two months & 6 & 12.50 \\
\hline total & $\mathbf{4 8}$ & $\mathbf{1 0 0}$ \\
\hline
\end{tabular}

In the study population, $43.75 \%$ of women started rehabilitation one month after the procedure; $35.42 \%$ waited two weeks, $12.50 \%$ more than two months and $8.33 \%$ one week.

The correlation coefficient indicates a moderate correlation; the power of correlation is significant.

The analysis demonstrated that women living in towns with $>100$ thousand inhabitants and 10-100 thousand inhabitants were most satisfied with the availability of rehabilitation; women living in the country and in towns with $<10$ thousand inhabitants were rather dissatisfied.

Table 5. Place of residence and satisfaction with availability of rehabilitation management

\begin{tabular}{|c|c|c|c|c|c|c|}
\hline \multirow[b]{2}{*}{ Place of residence } & \multicolumn{4}{|c|}{ Satisfaction with availability of rehabilitation } & \multicolumn{2}{|c|}{ total } \\
\hline & $\begin{array}{l}\text { Definitely } \\
\text { satisfied }\end{array}$ & $\begin{array}{c}\text { Rather } \\
\text { satisfied }\end{array}$ & $\begin{array}{c}\text { Rather } \\
\text { dissatisfied }\end{array}$ & $\begin{array}{l}\text { Definitely } \\
\text { dissatisfied }\end{array}$ & $\mathrm{n}$ & $\%$ \\
\hline country & 2 & 6 & 1 & 3 & 12 & 25.00 \\
\hline town $<10$ thousand inhabitants & 0 & 4 & 3 & 0 & 7 & 14.58 \\
\hline town - $10-100$ thousand inhabitants & 2 & 5 & 2 & 0 & 9 & 18.75 \\
\hline town $>100$ thousand inhabitants & 4 & 16 & 0 & 0 & 20 & 41.67 \\
\hline total & 8 & 31 & 6 & 3 & 48 & 100.00 \\
\hline
\end{tabular}

$\chi^{2}=14.36>\chi_{0.05: 9}^{2}=16.92$

$\mathrm{r}_{\mathrm{c}}=0.47$

Table 6. Kind of physiotherapy and assessment of its effectiveness

\begin{tabular}{|l|c|c|c|c|c|c|}
\hline \multirow{2}{*}{\multicolumn{1}{c}{ Kind of rehabilitation }} & \multicolumn{2}{c|}{ Assessment of satisfaction with rehabilitation } & \multicolumn{2}{c|}{ total } \\
\cline { 2 - 7 } & $\begin{array}{c}\text { Definitely } \\
\text { satisfied }\end{array}$ & $\begin{array}{c}\text { Rather } \\
\text { satisfied }\end{array}$ & $\begin{array}{c}\text { Rather } \\
\text { dissatisfied }\end{array}$ & $\begin{array}{c}\text { Definitely } \\
\text { dissatisfied }\end{array}$ & $\mathrm{n}$ & $\%$ \\
\hline Lymphatic drainage & 10 & 8 & 1 & 0 & 19 & 15.08 \\
\hline Rehabilitation exercises & 26 & 17 & 3 & 0 & 46 & 36.51 \\
\hline Pneumatic massage & 8 & 1 & 0 & 0 & 9 & 7.14 \\
\hline Whirlpool massage & 9 & 11 & 0 & 2 & 22 & 17.46 \\
\hline Vibratory massage & 2 & 4 & 0 & 1 & 7 & 5.56 \\
\hline Kinesiology Taping & 3 & 5 & 0 & 1 & 9 & 7.14 \\
\hline Compression & 4 & 9 & 1 & 0 & 14 & 11.11 \\
\hline total & $\mathbf{6 2}$ & $\mathbf{5 5}$ & $\mathbf{5}$ & $\mathbf{4}$ & $\mathbf{1 2 6}$ & $\mathbf{1 0 0 . 0 0}$ \\
\hline
\end{tabular}

$\chi^{2}=18.9>\chi_{0.05 ; 18}^{2}=29.5$

$\mathrm{r}_{\mathrm{c}}=0.53$ 
The correlation coefficient indicates a moderate correlation; power of correlation is significant.

In the study population, the following methods of rehabilitation were found most effective after mastectomy: whirlpool massage (17.46\%), followed by lymphatic drainage (15.08\%), kinesiology taping and pneumatic massage (7.14\%). The least effective method according to respondents was vibratory massage $(5.56 \%)$.

Table 7. Effects of physiotherapeutic procedures

\begin{tabular}{|l|c|c|}
\hline \multicolumn{1}{|c|}{ Effects } & n & \% \\
\hline $\begin{array}{l}\text { increased range of movement within } \\
\text { the shoulder girdle on the affected side }\end{array}$ & 31 & 29.81 \\
\hline $\begin{array}{l}\text { increased muscle strength of the upper } \\
\text { limb on the affected side }\end{array}$ & 14 & 13.46 \\
\hline reduced swelling & 25 & 24.04 \\
\hline reduced pain & 21 & 20.19 \\
\hline improved mental health & 13 & 12.50 \\
\hline total & $\mathbf{1 0 4}$ & $\mathbf{1 0 0 . 0 0}$ \\
\hline
\end{tabular}

The largest group consisted of women in whom physiotherapeutic management resulted in increased range of movement within the shoulder girdle on the affected side (29.81\%); reduced swelling was observed in $24.04 \%$, reduced pain in $20.19 \%$ whereas increased muscle strength of the lower limb on the affected side in $13.46 \%$ of women. Twelve percent of women reported improved mental status after physiotherapeutic management.

\section{Discussion}

Breast cancer is one of the most common malignant neoplasms. Irrespective of the type of surgical procedure performed, rehabilitation is an integral part of oncologic treatment. Physiotherapeutic management results in notable effects, i.e. improved lymph outflow, reduced swelling, improved motor performance of the limb. The most common problems are associated with the therapy of late lymphatic swelling of the upper limb [8].

The study by Kalinowski P, Krawulska A. [9] carried out in the group of 100 women after mastectomy demonstrated that the physiotherapeutic procedures patients found most effective included physical exercises (81\%) and massage (64\%). Moreover, patients emphasized too distant times of rehabilitation.

Skolimowska B. [10] assessed postures after breast cancer treatment in the group of 133 women attending motor exercises and otherwise. It was assumed that radical mastectomy results in impaired posture, which is functional and reversible with motor exercises in the majority of cases. The above assumption was found to be correct. In the group of patients who did not attend motor exercises, the unfavourable changes in the parameters analysed were observed.

According to Cerniak U. et al. [11], additional physical activity of women treated due to breast cancer markedly improved the composition and distribution of body components. The analysis was based on anthropometric measurements, including the bioelectrical analysis of impedance, and questionnaires filled by 70 women after mastectomy undertaking various forms of physical activity.

\section{CONCLUSIONS}

1. In the study population, $46 \%$ of respondents found post-mastectomy rehabilitation management effective.

2. Place of residence moderately affected satisfaction with availability of health care services. Women living in big towns were most satisfied. According to women living in the country and small towns, the availability of rehabilitation was unsatisfactory.

3. Types of physiotherapeutic procedures affected the level of satisfaction with rehabilitation. Rehabilitation exercises were assessed highly by $42 \%$ of women; vibratory massages were found to be the least effective procedures.

\section{References}

1. Czekanowski R. Choroby gruczołu sutkowego. Menopauza. Hormonalna terapia zastępcza. Warszawa 2003.

2. Kordek R., Jassem J., Krzanowski M., Jeziorski A., (red.). Onkologia - podręcznik dla studentów i lekarzy. Medical Press, Gdańsk 2003.

3. Wojciechowska U., Didkowska J., Zatoński W. Nowotwory złośliwe w Polsce w 2004, Centrum Onkologii - Instytut Warszawa 2006.

4. Mede J. Epidemia raka wyzwaniem XXI wieku. Szkolenie w zakresie psychoonkologii. Polska Unia Onkologii, Kraków 2006.

5. Pieróg B. Czynniki ryzyka kobiet po mastektomii. Fizjoterapia Polska, 1999;7, supl.1.

6. Pawlicki M. Rak Piersi i możliwości leczenia. A-medica Press, Bielsko Biała 2006.

7. Jassem J. (red). Rak Sutka. Podręcznik dla studentów i lekarzy. Springer PWN, Warszawa 1998.

8. Kołodziejski L, Niedbała E, Problems associated with physiotherapeutic management of patients after breast cancer surgery. Medical Rehabilitation 2008;12(2): 16-21.

9. Kalinowski P, Krawulska A. Rola fizjoterapii po mastektomii w opinii pacjentek. Medycyna Ogólna i Nauki o Zdrowiu 2012;4: 291-296.

10. Skolimowska B, Wpływ ćwiczeń ruchowych na postawę ciała kobiet leczonych $\mathrm{z}$ powodu raka piersi. Fizjoterapia 2005; 13(1): 18-27.

11. Czerniak U, Demutha A, Skrzypczak M. Associations of physical activity and inactivity with body tissue composition among healthy Polish women and women after mastectomy. Journal of Comparative Human Biology 2014. DOI: 10.1016/j. jchb.2014.03.005. 


\section{Correspondence address:}

Katarzyna Knott

Wydział Nauk o Zdrowiu, WSSP w Lublinie

Choiny 2, 20-816 Lublin

e-mail: katarzyna.knott@gmail.com 